\title{
ЕКСПЛИЦИТНА НАСТАВА, НАМЕРНО УЧЕЊЕ И САВРЕМЕНЕ МЕТОДЕ У ПОРЕБЕЊУ С ТРАДИЦИОНАЛНИМ УЧЕЊЕМ СТРАНОГ ЈЕЗИКА
}

\begin{abstract}
АПСТРАКТ
У овом раду ауторка приказује један од начина експлицитне наставе и намерног учења, примењујући технику попуњавања скице и износећи предности и мане у настави страног језика. Циљ истраживања је показати да ли је експлицитан начин наставе и намерног учења ефикаснији од класичног, фронталног начина предавања. Експлицитни вид наставе биће доминантан у овом истраживању. У истраживању су учествовале две групе ученика, распоређене у контролну и експерименталну групу. У раду је приказан и објашњен начин на који је ауторка спровела истраживање и износи добијене резултате који потврђују да техника има утицаја на ефикасност наставе страног језика. У уводном делу кроз теорију објасниће се важност комуникативног приступа у учењу страног језика, као и основне појмове који се користе, приказујући разлику између тестова краткорочне и дугорочне ретенције. Типови меморија, као и сваки тип понаособ, биће објашњени у раду. Ауторка ће направити разлику између намерног и ненамерног учења, повезати експлицитну наставу и технику попуњавање скице као један од њених примера, те изнети позитивне карактеристике технике кроз резултате које је добила током истраживања.
\end{abstract}

Кључне речи: тест, енглески језик, техника, резултати, експлицитна настава, намерно и ненамерно учење.

\section{EXPLICIT TEACHING, INTENTIONAL LEARNING AND MODERN TECHNIQUES IN COMPARISON WITH TRADITIONAL FOREIGN LANGUAGE TEACHING}

\begin{abstract}
In this paper the author shows one of the ways of explicit teaching and intentional learning, by applying the "Empty Outlines" technique. The aim
\end{abstract}


of this research is to determine how and to what extent the technique "Empty Outlines" may affect the teaching of English and the quality of knowledge of foreign languages. The advantages and disadvantages of the technique are presented when it is used in foreign language teaching. The explicit form of teaching a foreign language is dominant in the research. The study involved two groups of students: the control group and the experimental group. The author presents and explains the way in which the research was conducted and presents the results which confirm that the technique has an impact on the effectiveness of teaching foreign languages. In the introduction, the author explains not only the importance of the communicative approach in foreign language teaching but also basic terms used. The author clearly shows the difference between the tests of shortterm and long-term retention. Types of memory are also explained. The author makes a clear distinction between intentional and implicit learning. The paper connects explicit teaching and the technique of "Empty Outlines" as one of its examples, and explains the positive characteristics of the technique by the results obtained in the research.

Keywords: English teaching and learning, Empty Outlines technique, explicit teaching, intentional and implicit learning, language testing.

\section{1. УВОД}

Комуникативни приступ учењу страног језика у данашње време јесте једна од метода коју наставници који предају страни језик користе. Поред многих правила које ученици треба да савладају при учењу страног језика, умеће наставника види се у томе колико ће брзо и ефикасно научити своје ученике да језичка и граматичка правила што брже и боље примене у комуникацији страног језика, тако да веза међу њима буде природна и спонтана (Brown 1994: 15). Уз помоћ метода и техника које наставник примењује у настави изграђује се мост који повезује две тачке: с једне стране налази се тачка која представља теорију о језику, а другу тачку представља практична примена језика (комуникација).

Ауторка овог рада се у потпуности слаже са Брауном да не постоји ни правило, ни рецепт за примену неке од стандардних наставних метода, нити метода која се изводи брзо, лако и која гарантује успех. Сваки ученик и сваки наставник су јединствени, као што је свака веза између наставника и ученика јединствена, тако да наставник са̂м мора да пронађе начин на који ће успоставити и изградити однос са ђацима, а да при томе и резултати у учењу градива буду видљиви (Cross and Angelo 1993). 
У овом раду ауторка ће применти технику попуњавања скице (Empty Outlines). Ово је једна од техника која подразумева да се, уз помоћ попуњавања скица, празних места или линија, добије решење задатог задатка, а да ученици при његовој изради запамте што боље и брже предаване наставне јединице.

Техника попуњавања скице (Empty Outlines) спроводи се у настави на крају часа и траје свега неколико минута. Наставник ученицима најчешће подели папире на којима се налази задатак који подразумева попуњавање скице, празних места, речима или реченицама које су чули на часу.

Према досадашњим истраживањима, један од најчешћих проблема у спровођењу описане технике јесте дилема да ли је ученик озбиљно схватио задатак (Cross and Angelo 1993: 141). Други проблем који литература наводи јесте чињеница да ученици, уколико се ова техника често спроводи, на спровођење технике попуњавања скице почињу да гледају као на методу која нема сврху (Cross and Angelo 1993: 141).

Спровођење технике у настави има више предности:

- Наставник сазнаје да ли су студенти разумели предавано градиво.

- $\quad$ Наставник може да идентификује проблем и да одреагује на време.

- $\quad$ Побољшава се комуникација између наставника и ученика.

- Одговори ученика доводе до идеја како унапредити и побољшати предавања, као и које наставне јединице треба поново објаснити и обновити.

- $\quad$ Наставник може боље да упозна ученике и обрнуто.

- $\quad$ Техника може лако да се спроведе и у великим групама и да се на релативно брз начин добије повратна информација од ученика у вези са предаваном наставном јединицом (Cross and Angelo 1993: 140).

Када се наставник одлучи на примену наведене технику, мора бити спреман на кратке одговоре јер је ученицима потребно да се навикну на овакав вид наставе. Ако наставник покаже стрпљење, ученици стичу поверење, све више сарађују и постају заинтересованији (Brown 1994: 21). Тада начин провере знања постаје учење, у којем наставник има улогу некога ко им помаже, а да при том не суди. Ученици на овакву ситуацију гледају позитивно, почињу да комуницирају међусобно и дају 
конструктивне предлоге за наставу. Наставник охрабрује ученике који имају проблема и помаже им у циљу што бољег савлађивања наставних јединица.

Како Крос и Енџело (Cross and Angelo 1993: 148) тврде, постоји неколико начина примене технике попуњавања скице. Прво, сваки ученик може да ради за себе, може да се ради у паровима, након чега ученици могу да коментаришу своје одговоре и да се дискутују на одговарајућу тему. Техника, такође, може да се примени у групи од три до четири ученика и да се дискусија води тако да свака група дође до једног одговора који ће се презентовати пред осталим ученицима.

Аутори Чизмар и Остроски (Chizmar and Ostrosky 1998: 38) износе три начина помоћу којих техника попуњавања скице омогућава наставнику да побољша наставу. Прво, техника пружа наставнику детаљне информације о томе шта су и колико добро ученици савладали на часу, што је важно пошто наставник може на време да коригује и елиминише нејасноће у предавању, препреке у усвајању градива. Спровођење ове технике један је од начина да се ученици мотивишу, односно да се подстакну да буду активни и максимално ангажовани на часу.

У раду су наведене хипотезе, опис испитаника, опис материјала и инструмената за сакупљање података који су коришћени у истраживању, као и сам опис тока истраживања.

Циљ овог истраживања јесте да се провери ефикасност спровођења технике попуњавања скице у настави страног језика као један од примера за експлицитну наставу. Добијени резултати у овом истраживању показују да постоје многи разлози да се техника једноминутног одговора користи у настави страног језика. Квалитативна анализа података, добијена на тестовима након спровођења наведене технике у настави енглеског језика, потврђује да су испитаници савладали много боље градиво на часу на коме је примењена техника. Анализа одговора из упитника показује да су испитаници из експерименталне групе часове обраде тематске јединице оценили ефикаснијим и занимљивијим него што су то учинили испитаници контролне групе.

\section{2. ДЕФИНИЦИЈЕ ОСНОВНИХ ПОЈМОВА}

Ентони (Anthony 1963) је дао дефиниције три појма које наводимо у 254 наставку. По њему, постоје три хијерархијска елемента: приступ, метод и 
техника. Приступ је начин учења језика и подучавања. Метод је план за систематично презентовање језика које се заснива на изабраном приступу. Под термином техника Ентони подразумева специфичне активности и вежбе које се примењују за време часа, које су у хармоничном складу са методом и приступом. Наведене дефиниције су још увек актуелне међу наставницима страних језика (Brown 1994: 158).

Ричард и Роџерс (Richard and Rodgers 2001) реформулисали су концепт технике попуњавања скице. Хијерархијске елементе које је поставио Ентони (приступ, метода, техника), нови истраживачи заменили су терминима приступ, дизајн и поступак. По овим истраживачима, термин метод подразумева повезаност између теорије и праксе. Под термином приступ подразумевају се поступци и теорије о природи језика и учењу језика. Под термином дизајн подразумева се веза између теорије, материјала који се обрађује на часу и активности које се изводе за време часа. Поступци су технике и вежбе које произилазе из дизајна и приступа (Brown 1994: 159).

Реформулација термина и покушај додавања нових значења старим терминима није успео, бар не у педагогији (Brown 1994: 158). Дефиниција термина метод више се на неки начин односила на термин методологија. Затим се појавио и проблем коришћења термина дизајн, који се више односи на план и програм градива (Brown 1994: 159). Браун методологију види као науку која подразумева све оно на шта може да се одговори питањем: „како предавати?"

Под термином техника подразумевају се разноврсне вежбе и задаци, активности и средства коришћена у настави страног језика, како би се постигли и достигли што бољи циљеви у настави страног језика (Brown 1994: 160).

\section{1. Тест краткорочне и дугорочне ретенције}

У овом истраживању ауторка помиње две врсте тестова. Први тест је тест краткорочне ретенције (immediate post-test) и тест дугорочне ретенције (delayed post-test). У психологији, краткотрајна меморија дефинише се као део дуготрајне меморије у високом степену активације, односно као складиште информација којима се тренутно оперише и чији су капацитите ограничени, док је дуготрајна меморија део система обраде информација у ком су трајно ускладиштене информације у облику менталних 
репрезентација које процесе препознавања повезује са новим материјалом у радној меморији (Robinson 2003: 631).

\section{2. Врсте меморије}

Меморија је домен система обраде информација у ком се информације привремено или трајно складиште. Постоје три типа меморије: чулна, оперативна и дуготрајна (Robinson 2003: 631). Именоване три меморије разликују се по дужини задржавања материјала и по процесима који се у њима одвијају.

Чулна меморија је прва у низу компоненти система обраде информација. Ова меморија је когнитивни систем ограничених капацитета. У даљу обраду прослеђује се само део информација примљених од чула (Robinson 2003: 631).

Оперативна меморија је меморијски домен који служи за привремено складиштење и оперисање информацијама који поседује следеће карактеристике: она је краткотрајна, и може да се обнавља (Robinson 2003: 631).

Дуготрајна меморија је део система обраде информација у коме су трајно ускладиштене информације у облику менталних репрезентација, које процесе препознавања повезују са новим материјалом у радној меморији (Robinson 2003: 631).

\section{3. Намерно и ненамерно учење}

Када се, у когнитивној психологији говори о учењу, реч је о обради информација и меморији. Треба разликовати два појма: намерно и ненамерно учење (Hulstijn 2003: 349). Традиционално разликовање намерног од ненамерног учења огледа се у терминима учења и усвајања (Hulstijn 2003: 349).

Ненамерно учење јесте одсуство намере да се нешто научи, али имплицитно учење (implicit learning) подразумева усвајање материјала без свести о томе да се нешто учи.

Имплицитно учење (implicit learning) може бити само ненамерно (incidental learning) (Hulstijn 2003: 11).

Експлицитно учење подразумева свест у току учења, док намерно учење (intentional) означава постојање намере да се информација запамти. Различито тумачење ових термина последица је чињенице да је са̂м појам 
свесног (conscious) у учењу у великој мери различит, јер се под овим термином може подразумевати намера да се нешто научи (intentionality) (Hulstijn 2003: 371). У овом раду ауторка истиче ову врсту учења, дајући пример како техника попуњавања скице, као један од примера намерног учења, може да буде ефикасна и да доведе до бољег знања градива - у овом случају боље савладане наставне јединице у настави енглеског језка, у поређењу с истим наставним јединицама енглеског језика, предаваним на традиционалан начин.

Хулстејн (Hulstijn 2003: 373) сматра да ненамерно и намерно учење треба задржати пре свега из методолошких разлога. Тачније, уколико се испитаницима наговести да ће бити тестирани након обраде, учење постаје намерно, што је ауторка у свом истраживању и урадила.

\section{4. Експлицитна настава}

Улога експлицитне наставе јесте да усмери пажњу ученика на елементе при учењу које би они превидели, те да их оспособи да пореде оно што примете с оним што произведу (Ellis 1994: 362). Термин подизање свести (consciousness raising) подразумева облик наставе чији циљ није да ученика оспособи да произведе одређену структуру, већ да је разуме како би створио неку врсту когнитивне представе о њој.

Овај приступ требало би користити у случају када ученици немају ниво знања који би омогућио усвајање одређених одлика језика који уче (teachability hypothesis) (Ellis 1994: 643). Даути (Doughty 2003: 258-298) сматра да деца и одрасли не усвајају језик на исти начин, већ је реч о сасвим различитим когнитивним процесима. Деца просечне интелигенције и без наставе страног језика могу да науче страни језик тако да се не разликују од изворних говорника. То није случај с одраслима, јер се способности учења страног језика мењају кроз искуство учења матерњег језика, то јест при усвајању другог језика. Разлика између усвајања матерњег језика и страног језика јесте у томе што је оно што се примећује различито, и примарни задатак је пронаћи начин да се пажња одраслих усмери на кључне елементе у страном језику.

Декејсер (DeKeyser 2003) истиче да се одрасли при учењу страног језика ослањају на знање матерњег језика и да користе своје аналитичке способности. Аналитичке способности сваког појединца су различите. Елис (Ellis 2003) сматра да одрасли уче страни језик на основу постојећег 
концептуалног знања, и да најчешће уче језик уз помоћ свесног решавања проблема и дедукције.

Ауторка је применила технику попуњавања скице у настави енглеског језика као пример експлицитне наставе и намерног учења, те је добијене резултате на тестовима које је спровела након примене поменуте технике упоредила са добијеним резултатима на тестовима спроведеним након традиционалног предаваног градива.

Досадашња истраживања говоре о популарности примене технике попуњавања скице у настави природних предмета као што су биологија, хемија и физика. Међутим, ауторка је спровела технику у настави страног језика и потврдила да техника има изузетно позитиван утицај у учењу страног језика. Техника може да се примени врло брзо и једноставно како у малим тако и у великим групама ученика. Наставник има могућност да прати савлађивање градива и напредак својих ученика и тако добије тачан и детаљан увид у знање својих ученика и савладаност градива. Основни циљ је боље савладавање и разумевање градива, те стварање когнитивне слике о предаваним наставним јединицама.

\section{3. ХИПОТЕЗЕ}

У овом раду ауторка поставља следеће хипотезе:

Хипотеза X1: Применом технике попуњавања скице (Empty Outlines), једног од примера у којем се експлицитна наставе спроводи у настави страног језика, побољшава се знање страног језика.

Хипотеза X2: Испитаници из експерименталне групе показују изражено задовољство коришћењем специфичне технике попуњавања скице (Empty Outlines) у настави страног језика.

\section{1 Опис испитаника}

Истраживање је спроведено у Филолошкој гимназији у Сремским Карловцима. Учесници овог истраживања били су ученици треће године Филолошке гимназије, смера Савремени језици. Истраживање је обављено у одељењима пет и шест трећег разреда. Од укупног броја испитаника експерименталне групе, младића је било 6 или 25\% групе, а девојака је било 18 или 75\%, док су у контролној групи младићи чинили 20,84\% (5 ученика), а девојке 79,16\% (19 ученица) групе. 
Истраживање је обухватило две групе испитаника: контролну и експерименталну групу. Свака група имала је 24 ученика, а истраживање је спроведено у две етапе. Уз помоћ стандардизованог дијагностичког теста (English Diagnostic Test 1), који је био у облику теста вишеструког избора и садржавао педесет питања, утврђено је да испитаници који учествују у контролној и експерименталној групи владају високим средњим нивоом знања енглеског језика (upper-intermediate level или B2), тако да су на почетку истраживања били подељени у две групе, експерименталну и контролну. Групе су се разликовале само по односу броја младића и девојака који су их чинили.

Ученици који су учествовали у истраживању енглески језик су имали седам пута недељно - пет пута недељно имали су часове енглеског језика и два пута недељно технику превођења с енглеског на српски језик и обрнуто. Ауторка наглашава да је то језичка гимназија и да су одељења на часовима страног језика подељена у две језичке групе, са по 12 ученика. Међутим, за време истраживања језичке групе биле су спојене, тако да је истраживачица одмах добила два часа на располагању. Материјал, односно уџбеник који се користи за наставу енглеског језика за трећи разред ове гимназије јесте Opportunities (Harris, M. et al. 2002). Ауторка истиче да ученици нису навикли на улогу испитаника у истраживањима у научне сврхе, али су, пре него што је започето истаживање, обавили разговор с разредним старешином и психологом гимназије, који су им објаснили о каквом се истраживању ради. Врло значајно је напоменути да су ученици свој задатак и улогу у овом истраживању схватили и односили се према њему врло озбиљно, свесни чињенице да је ово истраживање спровођено како би истраживачица проценила колико је градиво савладано.

Ауторка напомиње да не ради у гимназији као професор и да ученицима није позната, те истиче да је то једини разлог због којег су се ученици на самом почетку истраживања устручавали да учествују у разговору. Међутим, већ након првих часова ова ситуација је била превазиђена, и атмосфера на часовима у току истраживања била је врло пријатна и пријатељска, што је ауторка након квалитативне и квантитативне анализе одговора и потврдила. 
3.2 Одабир материјала и инструмената за истраживање

Одабир наставних јединица на којима је примењена техника и урађено истраживање јесу јединице које су пратиле наставни план и програм. Ауторка је пре свега водила рачуна о томе да технику прилагоди наставном плану и програму. Крос (Cross and Angelo, 1993) тврди да свака техника не може да се примени за сваку наставну јединицу и да наставник треба да води рачуна око одабира техника.

Ефикасност технике коју је истраживачица применила у настави одмах је тестирана након часа, по завршетку малог одмора, у трајању од десет минута. Тестирање је изведено одмах након спровођења технике попуњавања скице, уз помоћ тестова вишеструког избора, да испитаници не би били превише оптерећени.

Десет дана од тренутка када је коришћена техника попуњавања скице, тестирано је продуктивно знање ученика уз помоћ теста допуњавања.

\section{3. Опис тока истраживања}

Истраживање је спроведено у пет фаза:

- Дијагностички тест

- $\quad$ Спровођење технике

- $\quad$ Тест краткорочне ретенције

- $\quad$ Тест дугорочне ретенције

- $\quad$ Анкетирање ученика

- Интервју

- Посматрање

У првој етапи истраживања испитаници су урадили дијагностички тест, на основу чега је утврђено да ученици на којима ће се извршити истраживање владају истим језичким нивоом, односно вишим средњим нивоом знања енглеског језика (upper-intermediate level), тако да су ученици на почетку истраживања били подељени у две скоро идентичне групе сексперименталну и контролну.

Након прве етапе истраживања примењена је техника попуњавања скице у експерименталној групи.

Трећа етапа истраживања извођена је након спровођења технике попуњавања скице.

Тестирање је обављено десет минута након што је ова техника спроведена. Четврта етапа истраживања спроведена је кроз одложени тест, 
мерењем дугорочне ретенције, две недеље после предавања. Тако су добијени подаци о томе колико су ученици заиста усвојили предавано градиво и у експерименталној и у контролној групи како на рецептивном тако и на когнитивном нивоу.

Након трећег теста, односно теста који су ученици радили после две недеље, подељена

им је анкета коју су попунили.

Одговорите на следећа питања:

1. Спроведена метода на часу енглеског језика је повећала је моју свест о томе шта нисам разумео/ла у току предавања.

а) Потпуно се слажем; б) Делимично се слажем; ц) Не слажем се;

2. Повратна информација о мом знању, коју сам добио/ла након спровођења технике, помогла ми је да боље разумем оно са чим сам заиста имао/ла потешкоћа.

а) Потпуно се слажем; б) Делимично се слажем; ц) Не слажем се;

3. Спроведена метода и коришћени инструменти од користи су ми за учење и спремање за даље тестирање.

а) Потпуно се слажем; б) Делимично се слажем; ц) Не слажем се;

Резултате тестова истраживачица је уносила у табелу истог дана када је и обављала ово тестирање. Последња фаза истраживања обухватила је интервју с изабраним ученицима.

\section{4 Часови обраде}

Часове обраде извела је са̂ма истраживачица. Одељења која су учествовала у истраживању деле се на две језичке групе, са два школска часа од по 45 минута, с малим одмором од 10 минута за експерименталну групу коју су чинили ученици једног одељења трећег разреда, и контролну групу коју су чинили ученици другог одељења трећег разреда. Обе групе имале су по 24 ученика који нису пропустили час обраде ни тестирања, што je идеална ситуација за истраживање. Техника попуњавања скице (Empty Outlines) спроведена је тако што су ученици на часу обраде слушали причу Чарлса Дикенса „The Pickwick Papers”, у којој има колокација које ученици треба да обраде, односно усвоје. 
Ученици и контролне и експерименталне групе радили су идентичне тестове с истим временским трајањем након спровођења технике, али у контролној групи техника попуњавања скице није примењена за време истраживања, већ су наставне јединице обрађене традиционалним начином предавања. У експерименталној групи истраживачица је наставу спровела уз помоћ наведене технике. Испитаницима у експерименталној групи сваки пут пред почетак часа на коме ће се спроводити техника јасно је објашњено шта је њихов задатак и шта се од њих очекује, као и чињеница да тестирање за време истраживања апсолутно неће утицати на њихову оцену и да им не може нашкодити, те да ученици тестове могу радити анонимно.

\section{4. ЧАСОВИ ОБРАДЕ ТЕХНИКЕ - ТЕХНИКА ПОПУЮАВАЮА СКИЦЕ (ЕМРТУ OUTLINES)}

У експерименталној групи ученицима су подељени картончићи на којима је требало да допуне реченице једним или два израза, и на тај начин понуде решење за одређену колокацију. На картону су се налазиле колокације које су могле да се чују за време слушања.

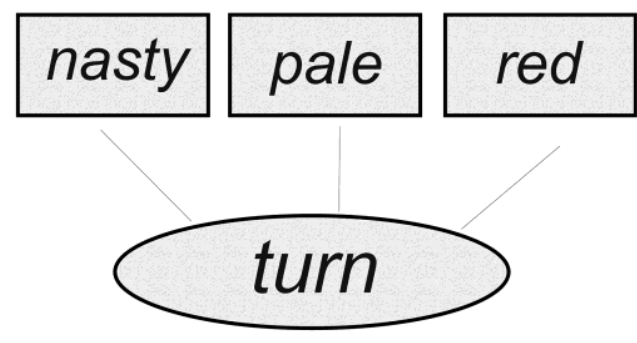

Sentence: She turned pale when she heard news.

\section{Слика 1: Пример колокаџије}

Испитаници из сваке групе у вежби слушања текста са ЦД-а могли су да чују по једну колокацију. Уколико је ученик чуо само једну од колокација и записао је, добио је решење за остале колокације на датој скици. Затим је следио задатак да за сваку колокацију понаособ напишу по једну реченицу, како би се проверило да ли је разумевање колокација 262 потпуно и да ли испитаници могу колокације да употребе у одређеном 
контексту. Уследила је пауза, након чега су испитаници добили тест вишеструког избора, обрађеног вокабулара на часу обраде.

\section{1. Мерење краткорочне ретенције}

Тестови вишеструког избора рађени су десет минута после завршетка обраде. Тест краткорочне ретенције не мери колико је градиво научено или усвојено, већ колико је скорашње, односно претходно учење било успешно. Тест које су испитаници радили одмах након часова обраде мерио је рецептивно знање. Учесници су на тесту добили по десет реченица. Свака реченица имала је по три понуђена одговора, те је требало да заокруже по један одговор за сваку реченицу.

\section{2. Мерење дугорочне ретенције}

Пимслер (Pimsleur 1967) тврди да је понављање градива након обраде веома важно. Због те чињенице учесници у истаживању наредна два часа понављали су и увежбавали предавано градиво и у експерименталној и у контролној групи, након чега је за наредну недељу најављено тестирање.

\section{3. Квалитативна анализа}

Квалитативна анализа у овом истраживању обухвата интервју и посматрање пет одабраних ученика. Скупљање података за квалитативну анализу обављено је након теста за мерење дугорочне ретенције.

У циљу прикупљања жељених података учесницима је обећана дискреција, односно потпуна анонимност на интервјуу. Истраживачица је, пре него што је започела интервју, односно одмах након што је изабрала испитанике из обе групе, нагласила да се интервју обавља искључиво у циљу допуњавања истраживања у коме су они учествовали. Учесници су инсистирали на томе да се интервју обави на српском језику, како би били у стању да изразе своје мишљење. У овом делу истраживања за квалитативну анализу изабрани су учесници који су били најактивнији за време часова обраде. За интервју је изабрано пет ученика, док је за време истраживања посматран рад свих ученика.

Коришћена питања у време интервјуа била су слична питањима која су се налазила у упитнику, а који су испитаници урадили први дан после спроведене технике попуњавања скице на часовима обраде. Ученици експерименталне групе били су активнији и више су учествовали у самој настави него што су то чинили ученици контролне групе. Ученици 
експрименталне групе показали су поред већег знања и веће интересовање за учење, те је утисак о успешности примене ове методе позитиван.

\section{4. Статистичке методе обраде података}

У овом раду обрада података урађена је у програму SPSS. Урађене су следеће анализе: фреквенцијска анализа узорка, израчунавање просечних вредности на тестовима знања и питањима из завршне анкете (израчунавањем аритметичких средина и стандардних девијација), т-тестови за независне узорке, којима је утврђена разлика у постигнућу испитаника из експерименталне и контролне групе на појединим тестовима.

\section{5. Резултати истраживања}

- Просечно постигнуће испитаника на тестовима

Просечно постигнуће обе групе испитаника на тестовима знања, после примењене технике у настави, исказано је путем аритметичких средина и стандардних девијација, на сумационим скоровима, за сваки тест посебно (Табела 1).

- Разлика у постигнућу на тестовима између контролне и експерименталне групе

Статистичка значајност разлике између контролне и експерименталне групе у постигнућу на тестовима знања проверавана је серијом т-тестова за независне узорке, у којима је независна варијабла била група (експериментална/контролна), док су скуп зависних чинили скорови на тестовима.

Разлика у постигнућу на тестовима између контролне и експерименталне групе може се приписати примењеној техници попуњавања скице.

Резултати показују да су на тесту, након примене технике попуњавања скице, испитаници из експерименталне групе постигли у просеку 7,8 поена, а испитаници из контролне групе 5,3 поена. Што се тиче завршног теста, испитаници из експерименталне групе у просеку су имали приближно 43 бода, а из контролне групе око 40 бодова (Табела 1) Максимално могући број бодова износио је 55. 


\begin{tabular}{|c|c|c|c|c|}
\hline & Група & $\begin{array}{l}\text { Број } \\
\text { испитаник } \\
\text { a } \\
\end{array}$ & $\begin{array}{l}\text { Аритметичк } \\
\text { а средина }\end{array}$ & $\begin{array}{l}\text { Стандардн } \\
\text { a } \\
\text { девијација }\end{array}$ \\
\hline \multirow{2}{*}{$\begin{array}{l}\text { Тест након } \\
\text { технике } \\
\text { попуњавањ } \\
\text { а скице }\end{array}$} & $\begin{array}{l}\text { Експериментал } \\
\text { на група } \\
\end{array}$ & 24 & 7,7619 & 1,64997 \\
\hline & $\begin{array}{l}\text { Контролна } \\
\text { група }\end{array}$ & 24 & 5,2963 & 2,17732 \\
\hline \multirow{2}{*}{$\begin{array}{l}\text { Завршни } \\
\text { тест }\end{array}$} & $\begin{array}{l}\text { Експериментал } \\
\text { на група }\end{array}$ & 24 & 43,4211 & 9,44581 \\
\hline & $\begin{array}{l}\text { Контролна } \\
\text { група }\end{array}$ & 24 & 40,0417 & 10,72075 \\
\hline
\end{tabular}

Табела 1: Аритметичка средина и стандардна девијаџија сумаџионих скорова на тестовима знања

Резултати показују да спровођење технике води до побољшања учења и добијања бољих резултата на тестирању (Cross and Angelo, 1993: 3). Статистичка значајност разлике између две групе испитаника у наведеним просечним постигнућима (аритметичким срединама) на тестовима знања, проверена је т-тестовима за независне узроке.

\begin{tabular}{|l|l|l|l|l|l|}
\hline & т-тест & $\begin{array}{l}\text { Дф- } \\
\text { степени } \\
\text { слободе }\end{array}$ & $\begin{array}{l}\text { п-ниво } \\
\text { значајнос } \\
\text { ти }\end{array}$ & $\begin{array}{l}\text { Разика } \\
\text { аритметичк } \\
\text { их средина }\end{array}$ & $\begin{array}{l}\text { Стандардн } \\
\text { а грешка } \\
\text { разлике }\end{array}$ \\
\hline $\begin{array}{l}\text { Тест } \\
\text { након } \\
\text { примене } \\
\text { технике } \\
\text { попуњава } \\
\text { ьа скице }\end{array}$ & 6,099 & 46 &, 000 & 2,4656 &, 40423 \\
\hline $\begin{array}{l}\text { Завршни } \\
\text { тест }\end{array}$ & 2,794 & 46 &, 030 & 3,3794 & 2,21022 \\
\hline
\end{tabular}

Табела 2: Разлика у постигнутим резултатима испитаника између експерименталне и контролне групе

Добијени резултати, исказани у Табели 2, показују да је разлика у постигнућу испитаника између експерименталне и контролне групе статистички значајна за тест након технике попуњавања скице, т= 6,099. Пошто су све разлике статистички значајне, а из Табеле 1 види се да су на свим тестовима испитаници из контролне групе постизали ниже скорове, 
можемо рећи да је техника примењена у експерименталној групи допринела да њихово постигнуће на тесту знања буде статистички значајно веће.

На основу свих наведених резултата може се рећи да испитаници из експерименталне групе у просеку на тестовима постижу више бодова од испитаника из контролне групе, тако да је хипотеза X1, која гласи: „Применом технике попуњавања скице у настави страног језика побољшава се знање страног језика" потврђена.

4.6. Просечни скорови испитаника експерименталне групе на питањима завршне анкете

Постигнуће испитаника на питањима завршне анкете испитивало се тако што су се израчунале аритметичке средине за сваки одговор. Поред аритметичких средина, израчуната је и стандардна девијација као мера распршења. Треба нагласити да су минималне вредности одговора износиле 1 бод, колико је вреднован одговор под $u$ ) не слажем се, док су максималне вредности одговора за свако питање износиле 3 бода, колико је вреднован одговор под а) потпуно се слажем.

\begin{tabular}{|l|l|l|l|l|}
\hline & Минимум & Максимум & $\begin{array}{l}\text { Аритметичка } \\
\text { средина }\end{array}$ & $\begin{array}{l}\text { Стандардна } \\
\text { девијација }\end{array}$ \\
\hline $\begin{array}{l}\text { Спроведена } \\
\text { метода на } \\
\text { часовима } \\
\text { енглеског језика } \\
\text { повећала је моју } \\
\text { свест о томе шта } \\
\text { нисам } \\
\text { разумео/ла у } \\
\text { току предавања }\end{array}$ & 2,00 & 3,00 & 2,0952 &, 29710 \\
\hline $\begin{array}{l}\text { Повратна } \\
\text { информација о } \\
\text { знању коју сам } \\
\text { добио/ла након } \\
\text { спровођења } \\
\text { технике помогла } \\
\text { ми је да боље } \\
\text { разумем оно са } \\
\text { чим сам имао/ла } \\
\text { потешкоћа }\end{array}$ & 1,00 & 3,00 & 2,8571 &, 47223 \\
\hline
\end{tabular}




\begin{tabular}{|c|c|c|c|c|}
\hline $\begin{array}{l}\text { Спроведене } \\
\text { методе и } \\
\text { коришћени } \\
\text { инструменти од } \\
\text { користи су ми за } \\
\text { учење и } \\
\text { спремање за } \\
\text { даље тестирање } \\
\end{array}$ & 2,00 & 3,00 & 2,0476 & ,21554 \\
\hline $\begin{array}{l}\text { Метода ми је } \\
\text { помогла да боље } \\
\text { разумем градиво } \\
\text { на часу }\end{array}$ & 2,00 & 3,00 & 2,8571 &, 35417 \\
\hline $\begin{array}{l}\text { Ова метода ми је } \\
\text { помогла да } \\
\text { добијем већу } \\
\text { оцену на } \\
\text { контролном } \\
\text { задатку }\end{array}$ & 1,00 & 3,00 & 2,7619 & 61721 \\
\hline $\begin{array}{l}\text { Препоручио/ла } \\
\text { бих наставнику } \\
\text { да примењује } \\
\text { ову методу у } \\
\text { настави } \\
\end{array}$ & 2,00 & 3,00 & 2,8571 &, 35417 \\
\hline $\begin{array}{l}\text { Ова техника, } \\
\text { спроведена у } \\
\text { настави } \\
\text { енглеског језика, } \\
\text { помогла би ми и } \\
\text { у другим } \\
\text { предметима } \\
\end{array}$ & 2,00 & 3,00 & 2,9048 & 29710 \\
\hline
\end{tabular}

Табела 3: Минималне и максималне вредности, аритметичке средине и стандардне девијације одговора на ставке упитника

На основу добијених резултата у Табели 3, можемо закључити да су испитаници у просеку највећу сагласност показали са следећим тврдњама:

„Ова техника, спроведена у настави енглеског језика, помогла би ми и у другим предметима”. (просечан скор 2,9); „Препоручио/ла бих наставнику да примењује ову методу у настави”; „Метода ми је помогла да боље разумем градиво на часу” и „Повратна информација о знању коју сам добио/ла након спровођења технике помогла ми је да боље разумем оно са 
чим сам заиста имао/ла потешкоћа". Сви наведени одговори имају просечан скор 2,8 .

Наведени резултати дају нам за право да кажемо да је хипотеза X1: „Испитаници из експерименталне групе показују изражено задовољство коришћењем специфичне технике у настави страног језика" потврђена. Наведена хипотеза потврђена је и квалитативном методом: учесници у истраживању који су учествовали у унтервјуу одговорима на постављена питања потврдили су поменуту хипотезу.

Испитаници су истакли да су задовољни спроведеном техником, као и да, захваљујући њој могу боље и брже да савладају градиво. Осим тога, недоумице које су постојале у вези с неким делом градива спровођењем ове технике су разрешене, а од велике помоћи била им је и чињеница да им је наставник скренуо пажњу на неке од колокација на самој настави.

\section{5. ЗАКЉУЧАК}

Након спроведеног истраживања технике попуњавања скице у настави енглеског језика, потврђена је претпоставка да ова техника позитивно утиче на усвајање знања.

Управо због позитивних резултата који су добијени спровођењем ове технике као један од видова презентације наставних јединица на експлицитан начин, наставници треба да буду још мотивисанији за побољшавање и унапређивање наставе страног језика. Један од начина је управо примена техника и различитих метода како би се побољшало знање страног језика, а да при том ниво уживања на часу постане неупоредиво већи у поређењу са часовима на којима је изведен традиционалан начин предавања (Cross and Angelo, 1993), што су испитаници, путем интервјуа и завршне анкете коју је истраживачица спровела након спровођења технике, и потврдили.

Након квантитативне и квалитативне анализе, доказано је и статистички да спровођење технике која се помиње у овом истраживању чини наставу енглеског језика ефикаснијом. Ефикасност техника се понекад може видети чак и на истом часу када се техника и спроводи (Cross and Angelo, 1993: 4). 


\section{ЛИТЕРАТУРА}

Angelo, Thomas A. and Cross, K. Patricia (1993). Classroom assessment techniques: A handbook for college teachers. $2^{\text {nd }}$ edition. San Francisco: Jossey-Bass Publishers.

Anthony, Edward M. (1963). “Approach, Method, and Technique”. ELT Journal XVII (2): 63-67.

Brown, H. D. (1994). Principles of Language Learning and Teaching. New Jersey: Eaglewood Cliffs.

Chizmar, John A. and Ostrosky, Anthony L, (1998). "The One-Minute Paper: Some Empirical Findings". The Journal od Economic Education Vol. 29, Issue 1:3-10

DeKeyser, R. (2003). "Implicit and Explicit Learning", in The Handbook of Second Language Acquisition, eds. Catherine J. Doughty, Michael H. Long (Oxford: Blackwell Publishing Ltd, Oxford, UK ): p. 232-259.

Doughty, C. J.(2003). "Instructed SLA: Constraints, Compensation, and Enhancement”, in The Handbook of Second Language Acquisition, eds. Catherine J. Doughty, Michael H. Long (Oxford: Blackwell Publishing Ltd, Oxford, UK ): p. 198-230.

Ellis, R. (1994). The study of second language acquisition. Oxford: Oxford University Press.

Ellis R. (2003). Task-based Language Learning and Teaching. Oxford: Oxford University Press.

Ellis, R. (2014). "Taking the critics to task: The case for task-based teaching". Proceedings of Clasic 2014: 103-117.

Harris, M. et al. (2002). "Opportunities Upper- Intermediate - Student's Book". Приступљено 11. 3. 2015.

URL: <http://www.fas.nus.edu.sg/cls/CLaSIC/clasic2014/Proceedings/ellis_rod.pdf>.

Hulstijn, J. (2003). "Incidental and Intentional Learning", in The Handbook of Second Language Acquisition, eds. Catherine J. Doughty, Michael H. Long. (Oxford: Blackwell Publishing). URL: <https://www.scribd.com/document/72360306/ English-Diagnostic-Test-1>. March 2016.

Pimsleur, P. (1967). “A Memory Schedule”. The Modern Language Journal 51/2: 73-75.

Richard, Jack C. and Rodgers, Theodore S. (2001). Approaches and Methods in Language Teaching (2nd ed). Cambridge, New York: Cambridge University Press.

Robinson, P. (2003). "Attention and Memory during SLA", in The Handbook of Second Language Acquisitioni, eds. Catherine J. Doughty, Michael H. Long (Oxford: Blackwell Publishing): 631-678. 
Maja Lemajić

\title{
EXPLICIT TEACHING, INTENTIONAL LEARNING AND MODERN TECHNIQUES IN COMPARISON WITH TRADITIONAL FOREIGN LANGUAGE TEACHING
}

\begin{abstract}
Summary
In this paper the author shows one of the ways of explicit teaching and intentional learning, by applying the "Empty Outlines" technique. The subject of this research is to determine how and to what extent the technique "Empty Outlines" may affect the teaching of English and the quality of knowledge of foreign languages. The advantages and disadvantages of the technique are presented when it is used in foreign language teaching. The explicit form of teaching a foreign language is dominant in the research. Previous research checked the efficiency of the technique in science teaching and proved that the technique had a major impact on improving the quality of not only teaching, but also the students' knowledge in physics, mathematics, biology and medicine. The study involved two groups of students: the control group and the experimental group. The author presents and explains the way in which the research was conducted in Grammar School in Sremski Karlovci, Department of Modern Languages. Quantitative data was obtained by statisticaly analysing the immediate-post tests and the long-term retention test. Qualitative research was also conducted. It included interviews and observations in the class treatment at the end of the quantitative research The results confirm that the technique has an impact on the effectiveness of teaching foreign languages. In the introduction of the paper, the author explains not only the importance of the communicative approach in foreign language teaching but also basic terms used. The author clearly shows the difference between tests of short-term and long-term retention. Types of memory are also explained. The author makes a clear distinction between intentional and implicit learning. The paper connects explicit teaching and the technique "Empty Outlines" as one of its examples, and explains the positive characteristics of the technique by the results obtained in the research.
\end{abstract}

Keywords: English teaching and learning, Empty Outlines technique, explicit teaching, intentional and implicit learning, language testing.

Primljeno: 29.4.2017. Prihvaćeno: 7.8.2017. 